\title{
Hva vil russerne med Norge?
}

\author{
Bernhard L. Mohr \\ Oslo: Cappelen Damm 2020 \\ 237 sider. ISBN 9788202629090
}

Omtalt av Øyvind Nordsletten [tidlegare norsk ambassadør i Moskva, oyvind@, nordsletten.com]

Med Russland som nabo i eit strategisk viktig område, er det ikkje anna å venta enn at litteraturen om det store grannelandet kvart år tel mange bøker. Mange av dei, slik som Halvor Tjønns breidt anlagte Russland blir til frå 2015, tek føre seg ulike sider ved utviklinga i fortid og nåtid i Russland sjølv. Andre er meir spesifikt vigd forholdet til Noreg. Med storverket i to bind (Norge-Russland 1814-1917 og Norge-Russland 1917-2014) på godt over 1000 sider om det asymmetriske norsk-russiske naboskapet, kom det i 2015 ei autoritativ og oppdatert framstilling av det bilaterale tilhøvet i perioden frå 1814 til 2014. Dette verket utmerker seg likeeins ved at det er eit unikt fellesprosjekt, og resultatet av eit årelangt og fruktbart samarbeid mellom historikarar og fagfolk i dei to land.

Ei mindre omfattande, men likevel høgst lesverdig og nyttig ajourføring av sentrale spørsmål og tema som i dag pregar substans og temperatur i det tosidige tilhøvet, er journalisten og mediamannen Bernhard L. Mohr si bok Hva vil russerne med Norge? Mohr har langvarige opphald i Russland bak seg, både som student og medarbeidar i mediabransjen. I 2017 ga han ut boka Hvorfor stemmer russerne på Putin?, denne òg eit verdifullt bidrag til innsikt i drivkreftene i det 21 . århundrets Russland.

Som tittelen indikerer, er det $\mathrm{i}$ årets bok Mohrs ambisjon å formidla og forklara korleis russarar flest, ikkje minst yngre menneske, ser på Noreg. Like viktig er det samstundes å ettergå kva som motiverer det russiske leiarskap og styresmakter når dei formulerer haldningar og politikk andsynes grannelandet i nordvest. Mohr vaktar seg likevel for å opptre som apologet for russiske synsmåtar. Ved å gjennomgå russisk argumentasjon og tenking omkring forholdet til Noreg, set han seg som oppgåve å gje lesaren djupare forståing av dei meir komplekse samanhengar som ikkje alltid kjem fram i den daglege straumen av analysar og kommentarar. Og om boka sin tittel seier noko anna, vinn ho òg på like mykje å framstå som innfallsport til å forstå norsk russlandspolitikk og nordmenns syn på den store nabo. 
Mohr si framstilling er lettlesen utan å vera lettvint. Du vil leita forgjeves etter statsvitenskapeleg teoretisering om stormakt kontra småstat. Derimot vil du finna oversiktlige gjennomgangar av dei fleste dagsaktuelle hovudspørsmål i naboforholdet; alt frå den tryggingspolitiske utviklinga i nord, konsekvensane av anneksjonen av Krim og det ikkje alltid enkle samlivet på Svalbard, til verknaden av russiske informasjons- og påverknadsstrategiar. Konkrete enkeltsaker, som den nylege spionsaka med Frode Berg, gjer han utførleg greie for og set inn i sin større samanheng og perspektiv.

Fellesnemnaren for tyngda av dei spørsmål Mohr tek opp, er naturleg nok det som inneheld stridstema og konfliktpotensial. Dette hindrar likevel ikkje at han samstundes får klart fram dei mange positive elementa i tilhøvet, anten det nå gjeld den tusenårige fredstradisjonen på vår felles grense, alliansen og den sovjetiske frigjeringa av Aust-Finnmark under krigen, eller Barents-samarbeidet og det omfattande samarbeidet i moderne tid på område som fiskeri og miljø. Eit viktig poeng i denne samanheng er òg påvisinga av at det bilaterale forholdet, som inntil for tredve år sidan fyrst og fremst var regjering og sentrale styresmakters domene, takka vere åpnare grenser og innvandring - den russiske diasporaen i Noreg tel bortimot 20000 menneske - i dag er langt mindre eindimensjonalt.

Som mediamenneske er Mohr oppteken av persepsjonar og omdøme. Han påviser tydeleg korleis tonen i russiske oppfatningar av Noreg i mange samanhengar er skjerpa i negativ retning som fylgje av framveksten av antivestlege straumdrag i Russland. Men, heller ikkje her er det svart-kvitt. Parallelt med eit russisk TV program som demoniserer Noreg ("Ugroza s severa»), rullar rosande portrett over skjermen i beste sendetid. Denne dualismen er, slik Mohr syner det, i det heile symptomatisk for oppfatningane av naboen i meir generell forstand. To diametralt ulike rammeforteljingar gjer seg gjeldande på begge hald. I den eine er naboen konstruktiv partnar, i den andre utfordrar og potensiell motstandar.

Mohrs framstilling inneheld ei mengd fakta og konkrete opplysningar. Diverre er ikkje alt like korrekt. Såleis ligg dei to avanserte skipsverfta Sevmasj og Zvezdotsjka ikkje ved Murmansk-fjorden, men ved Kvitsjøen (s. 114), Murmansk-fjorden ligg heller ikkje på langt nær 100 mil frå norskegrensa (s. 126), det malaysiske flyet vart skote ned over Ukraina i juli 2014 og ikkje i august (s. 90), og påstanden på side 142 om at russiske offshoreinstallasjonar i Arktis vil produsera 31-35 tonn olje i 2035, burde både forfattar og redaktør ha innsett er meiningslaus. Desse og eit par andre moment av tilsvarande karakter vert likevel bagatellar målt mot det kunnskapstilfang som ellers underbyggjer og ber framstillinga.

Noreg sitt tilhøve til Russland vert i stor grad definert av to overgripande faktorar. På den eine sida er vi naboland, som gjennom århundre har makta å finna ut av det med kvarandre på rimeleg rasjonelt vis. Samstundes skil våre respektive samfunnssystem og tryggingspolitiske orientering seg tydeleg frå kvarandre. Svaret på dette har for vår del tradisjonelt vore å søkja tryggleik i alliansefellesskapet 
kombinert med utvikling av eit pragmatisk samarbeid, dialog og ei brei kontaktflate austover både til styresmakter og det sivile samfunn. Med Russlands stadig meir markerte evne og vilje til å demonstrera makt i våre nærområde, er det ingen grunn til å tru at denne balansegangen vil verta mindre komplisert og krevjande $\mathrm{i}$ framtida. For den som skal orientera seg og navigera i dette farvatnet, vil Bernhard L. Mohrs analyser og resonnement framstå som nyttige hjelpemiddel og velfundert stoff til ettertanke. 